Article

\title{
Normative Power Europe as an Ingroup Projection? The EU's Response to the Arab Uprising
}

\author{
Juan José Tapia-León *(D) and Emilio Galdeano-Gómez \\ Department of Economics and Business, Mediterranean Research Center on Economics and Sustainable \\ Development (CIMEDES), 04120 Almería, Spain; galdeano@ual.es \\ * Correspondence: tlj354@ual.es
}

Received: 20 March 2020; Accepted: 13 May 2020; Published: 14 May 2020

check for updates

\begin{abstract}
This paper aims to understand the social-psychological dimension of the Normative Power Europe discourse using ingroup projection as a discursive/cognitive practice of othering. It takes issue with most poststructuralist studies that conduct analyses of Normative Power Europe based on the dependence of identity on difference through the discursive tendency to construct reality by opposites. Ingroup projection is based both on the need for differentiation to obtain positive distinctiveness and on the natural tendency for categorization processes by which groups share a common higher-order category. In this way, groups tend to project (ingroup projection) their traits and distinctive values onto this higher-order category to legitimate intergroup status differences. The EU's response to the Arab uprisings serves as an empirical test for this argument, insofar as the uprisings implied a cognitive change of the EU's "other" in the construction of the Mediterranean. Through ingroup projection, the EU (ingroup) differentiates itself from this new Arab Mediterranean other (outgroup) and projects EU's idealized identity onto the Mediterranean region (higher-order category) to legitimate its new policies after the uprising.
\end{abstract}

Keywords: Normative Power Europe; ingroup projection; discourse analysis; Arab uprising; Mediterranean region; social psychology; foreign policy

\section{Introduction}

The literature on international relations regarding the EU's actorness (as a civilian, normative, transformative, realist or market power) with critical lenses has grown in recent decades (Cebeci 2012; Cebeci and Schumacher 2017; Diez 2005; Neumann 1998; Nicolaïdis and Howse 2002; Rumelili 2004). These studies are largely grounded in a poststructuralist tradition that treats foreign policy as a discursive practice that builds social reality. Such studies mainly base their analysis on the EU's discourse, understanding it as a "series of representations and practices through which meanings are produced, identities constituted, and social relations established" (Campbell 2013, p. 234). What makes the difference in relation with other social-constructivist approaches is the dependence of identity on difference (Rumelili 2004; Hansen 2006) supported by many of these studies.

The dependence of identity on difference is grounded in not only the discursive tendency to construct social reality through opposites (Doty 1996) but also the cognitive tendency to categorize as a form of producing meaning, structure and security in the social world (Tajfel and Turner 1986). Most poststructuralist studies, based on this dependence, ignore this cognitive tendency. This paper intends to enrich poststructuralist studies of the EU's actorness based on the dependence of identity on difference, adding the cognitive tendency to categorize. The purpose is to obtain the social psychological dimension of Normative Power Europe's (NPE) discourse through the inclusion of ingroup projection as a discursive/cognitive practice of "othering". 
The ingroup projection model (IPM) bases its premises on both social identity theory (SIT) (Tajfel and Turner 1986), according to which ingroups tend to differentiate from relevant outgroups in their social context to obtain positive distinctiveness, and self-categorization theory (SCT) (Turner 1987), which stresses the cognitive inclination to categorize. From the merging of both theories arises the concept of ingroup projection, which indicates the tendency to project traits and distinctive ingroup values to a higher-order category that works as a normative reference for intergroup comparison among the groups included. In this way, the greater the ingroup projection is, the stronger the perception of legitimacy in intergroup relations, which justifies the power/status differences among subgroups (Weber et al. 2002).

This article follows a discourse-historical approach (DHA) (Wodak 2001; Aydın-Düzgit 2014). DHA belongs to the plurality and diversity of theoretical and methodological approaches that are included in critical discourse studies. Its emphasis on identity constructions through "the discursive construction of ' $u s^{\prime}$ and 'them' as the basic foundations of discourses of identity and difference" (Wodak 2001, p. 73) makes the DHA particularly interesting in addressing critical analysis on the co-constitutive nature of European Foreign Policy and European Identity (Nicolaïdis and Howse 2002; Diez 2005; Hansen 2006; Cebeci 2012; Cebeci and Schumacher 2017). However, DHA does not feature prominently in EU studies (Aydın-Düzgit 2014).

The centrality of DHA is the application of discursive strategies to answer empirical research questions such as: How are the chosen subjects named and referred to linguistically? What traits, characteristics, qualities and features are attributed to them? Through what arguments and argumentation schemes are certain representations of the subjects justified, legitimized and naturalized in discourse? (Wodak 2001, pp. 73-74). Discursive strategies are usually a mixture of reference/nomination strategies to generate ingroups and outgroups within the discourse (uses of the names "we" and "they"; use of metaphors, metonymies and tropes in general), predication strategies to designate qualities to ingroups and outgroups (through the use of adjectives, attributes or values) and argumentation strategies to justify the attributes assigned to ingroups and outgroups. In argumentation strategies, the most common characteristic is the use of topos, defined as "parts of argumentation which belong to the obligatory, either explicit or inferable premises in the shape of content-related warrants that connect arguments with conclusion" (Reisigl and Wodak 2001, p. 74). For example, topos such as threat, culture and history are widely used in the discursive constructions of national identities.

In this sense, the EU's ingroup projection as a discursive practice of differentiation within the NPE discourse contributes to the DHA by adding cognitive practice. The dynamics of the ingroup projection are similar to the dynamics of any discursive strategy in the sense that it implies a (cognitive) differentiation between ingroups and outgroups into distinctive positive values (referential/nominative and predication strategies), projecting these values into a higher-order category that serves as a framework for reference and, therefore, as a basis for the legitimation of intergroup relations (argumentation strategies). In this study, we conceive the EU's ingroup projection as a discursive/cognitive practice of NPE discourse as a wide discursive strategy

The EU's response to the Arab uprisings serves to substantiate the assumptions of the paper insofar as uprisings involve first and foremost a cognitive change of the EU's other in the Mediterranean region. A change produced by Arab people both reclassifies the people themselves and changes the meanings and boundaries ascribed to their former identities (Rumelili and Todd 2018), developing a new Arab Mediterranean identity. Hence, focusing on the new intergroup relationship between the EU and the new Arab identity, the paper presents a concrete illustration of how ingroup projection as a discursive/cognitive practice of othering can explain the EU's response to the Arab uprising.

The paper aims to answer some of the empirical questions that studies on critical discourse analyses have established but adapts them to both the cognitive dimension of our analysis and the context of the Arab uprising: How does the EU discursively (and cognitively) construct the Mediterranean as a region after the Arab uprising? How is this new Arab identity represented? How is this new discursive (and cognitive) representation legitimized? (Wodak 2001; Hansen 2006). To answer these questions, 
the research carried out in this study comprises an in-depth analysis of all the relevant EU official documents directly related to the EU's response to the Arab uprising as well as speeches of the High Representative for Foreign Affairs and Security Policy/Vice-President of the European Commission and the Commissioners responsible for the European Neighbourhood Policy (ENP). It also involved a comprehensive literature review of relevant articles published in journals directly related to the Arab uprising events.

The paper is structured as follows. The first two sections focus on the theoretical and empirical developments of NPE's discourse and the IPM. The third section discusses the conceptualization of ingroup projection as a discursive practice of othering, focusing on the EU's discursive constructions of the Mediterranean region. The last section, focusing on the EU's response to the Arab uprisings as an empirical test, intends to demonstrate that the EU's ingroup projection as a discursive/cognitive practice of differentiation embedded in the NPE discourse explains and legitimates the EU's policies towards the Mediterranean region after the uprising.

\section{Normative Power Europe}

The NPE approach is framed in a broader debate about the interconnectedness between collective identities and foreign policy in which constructivists (liberal and more critical/poststructuralists) have been involved since the 1990s. Poststructuralists stress how identity is constructed by drawing boundaries between the self and its others. Taking Campbell's description of foreign policy as "a particular resolution of the categories of identity and difference", implying "all practices of differentiation or modes of exclusion that constitute their objects as foreign in the process of dealing with them" (Campbell 1998, p. 68), one could assume that foreign policy aims to classify/categorize both inside and outside as a means of boundary-drawing identity exercise. In this line, Hansen (2006) argues that "there can be no understanding of development policies without a description of who the underdeveloped are, where they differ from the developed West, and how they can transform their identity. Foreign policies are legitimized as necessary [...] through reference to identities". Following Hansen, the salient question here is the co-constitutive nature of identities and foreign policy. The European identity cannot emerge without an understanding of its constitutive other, to what extent the others deviate from European identity and how they can become more "European" or, at least, whether they can behave according to European norms and values. Building the self/other relations through difference, European foreign policy is legitimated by claiming the positive value of the European identity against its others, as revealed by the NPE discourse.

The NPE discourse is based mainly on the fact that the EU has a unique and exclusive identitya normatively different identity (Manners 2002; Manners and Whitman 2003). Such normativity enables the EU to shape what is considered to be "normal" in external relations with others (Manners 2002, p. 253). Through NPE, the EU both represents and promotes universal values such as democracy, rule of law, human rights, freedom, equality and peace. These are the values that the normative European identity rests on when it has to interact with its "others". In this sense, Diez (2013, p. 626) stresses that normative power is a "practice of discursive representation". He argues that NPE is not an "objective category" (Diez 2005, p. 613); rather, such discursive representation creates an identity of the "self" by turning third parties into "others", thus representing the EU as a positive force in world politics. Because the difference is normative, the EU's identity legitimately establishes what is normal in international politics. Such a normative nature in the construction of the European self along with its representation in a positive way makes the EU both a "virtuous example" (Manners 2002, p. 244) and an "ideal" type (Cebeci 2012). International actors holding such normative identities can set the norms by which others are governed and therefore reproduce a superior sense of self.

Following Diez's (2005) conceptualization of NPE as a discursive representation of European identity in terms of "othering" practices, research on region-building has been salient in studies of European foreign policy in recent years, especially the construction of Europe through EU enlargements and the Mediterranean as a region that delineates "northern" and "southern" identities. 
Regarding the EU's enlargement to Central and Eastern Europe, the practice of "othering" was less intense in the sense that Central and Eastern countries were viewed as "less" European than earlier members states of the EU and not inherently different. However, some authors argue that in the enlargement process, there was no practice of othering since this process may be viewed as a common inclusive identity (Schimmelfennig 2001), an identity actively sought by the governments of these countries by emphasizing a common historical ground (Neumann 1998). In contrast, Rumelili (2004), relying on "modes of differentiation", argues that the production of differences may be based on either inherent or acquired characteristics. Hence, although Central and Eastern countries are inherently European, acquired characteristics, such as the Copenhagen criteria ${ }^{1}$, also play an important function in the production of differences. Through the Copenhagen criteria as a practice of othering, the EU not only sets the parameters of what is Europe but "it also has the recourse of being able to claim almost a sole monopoly on what can be called 'European-ness'" (Haukkala 2011). The enlargement process not only redefined the EU's geographical boundaries but also outlined the new EU's identity boundaries with new others. Are practices of othering applicable to these new others? The European Neighbourhood Policy (ENP) was designed to some extent to answer this question.

The ENP was intended to guide the relationship between the EU and its southern Mediterranean neighbours. There exists a wide consensus among scholars that the Mediterranean is a constructed region politically and ideologically because it does not exist (Nicolaïdis and Nicolaïdis 2006) but "is first and foremost a European construct" (Cebeci and Schumacher 2017, p. 4). Some authors have already observed the Barcelona Process ${ }^{2}$ as a constructed region where "one size fits all" (Bicchi 2006). All these articulations of the Mediterranean region favour the wider Europe version, as specified in the official document of the ENP (Commission of the European Communities 2003). It seems to suggest that the engagement of the EU in the Mediterranean is largely grounded in normative standardsin other words, the exportation and reproduction of the successful model of regional integration within Europe towards the southern Mediterranean. These Mediterranean images with "European eyes" try to normatively legitimate the European Union as a "force for good" in the region.

To sum up, we have theorized the NPE discourse from the idealization of Europe through "othering" practices. We adopt social psychology to deepen our understanding of NPE as a discursive representation of European identity and develop the social-psychological dimension of this concept.

\section{Ingroup Projection}

A substantial body of research in social psychology has revealed that social categorizations into "us" and "them" drive intergroup conflict. The results regarding the minimal group paradigm (Tajfel et al. 1971) ${ }^{3}$ led Tajfel and Turner (1986) to develop the foundations of SIT, which suggests that belonging to a group grants a sense of who we are-that is, a social identity. The natural tendency is to positively evaluate such a social identity through comparison with relevant "others". On the other hand, SCT (Turner 1987) shows that categorization processes are essential in people's minds to either provide meaning or structure or to secure their social world. Through the categorization process, differences within one self-category fade, while differences from other relevant categories become more accentuated. Another aspect of SCT is that categories are structured hierarchically; this means that comparative evaluations between categories are possible because of their inclusion in a higher-order category. In other words, higher-order categories provide the comparative dimensions to the subcategories included.

\footnotetext{
The Copenhagen criteria are the essential conditions all candidate countries must satisfy to become member states. The Barcelona Process was born to convert the Mediterranean region into a common space for peace, stability, prosperity and security in 1995.

3 Minimal group experiments have demonstrated that even random or non-existent categorizations with no prior shared history or meaning can induce negative intergroup evaluations.
} 
The categorization process can be described as follows (Wenzel et al. 2007). First, subgroups are comparable to the extent to which they share a more inclusive higher-order category. Second, subgroups tend to be compared on dimensions that define and give meaning to that higher-order category. Third, the higher-order category prototype, defined as "the ideal type member of a category that bests represents its identity in a given context and frame of reference" (Oakes et al. 1998, p. 75), is the value standard and relevant norm for subgroup comparisons. Striving for positive distinctiveness would lead to the claim that the prototype of the higher-order category is best expressed in terms of one's subgroup prototype. This process may be understood as if subgroup members project their distinctive characteristics onto the inclusive higher-order category.

The tendency to use ingroup values and norms as a reference standard to evaluate intergroup differences is described by the concept of ethnocentrism. Evaluating others under ingroup standards inevitably leads to a sense of superiority in the ingroup and negative evaluations of the outgroups. In other words, ethnocentric conceptions understand the social world as pars pro toto. Turner (1987, p. 61) explicitly links the concepts of ethnocentrism and ingroup projection, since "ethnocentrism [...] depends upon the perceived prototypicality of the ingroup [...] in terms of the valued superordinate self-category that provides the basis of the intergroup comparison". The latter forms the central piece of the IPM-defining ingroup projection as "the perception, or claim, of the ingroup's greater relative prototypicality ${ }^{4}$ for the superordinate group" (Wenzel et al. 2007, p. 337).

The empirical evidence that supports such theoretical considerations has been growing since the early 2000s. A detailed discussion of these studies is beyond the scope of this paper ${ }^{5}$. We aim to focus on empirical evidence that helps us substantiate the arguments of this study.

Especially relevant is how ingroup projection relates to perceptions of legitimacy. Weber, Mummendey and Waldzus (2004) have shown that the greater the ingroup projection is, the greater the perceived legitimacy of status differences (see also Reese et al. 2012). Differences in the relative prototypicality of both subgroups mean differences in conformity with the norm, acknowledging that the higher-order category represents the normative comparative standard. By contrast, illegitimate relationships facilitate alternatives to the status quo that stimulate low-status groups to enhance their position (Ellemers et al. 1993). Context dependency, be it social, historical or ideological, has shown its relevance in intergroup relations as well. In Germany, for instance, both East and West Germans agree that the relative prototypicality of West Germany is more prototypical for the higher-order German identity than East Germany (Waldzus et al. 2004).

The IPM suggests two predictors of ingroup projection: social identification and characteristics of category representation. Regarding the former, those who identify with both the subgroup and the higher-order category show a greater tendency toward ingroup projection to further enhance the ingroup's positive distinctiveness and relative status (Wenzel et al. 2003; Waldzus et al. 2003; Ullrich et al. 2006). About ingroup projection and higher-order identities, even in more abstract instances, there is room for ingroup projection. That is the case with higher-order categories such as humanity (Reese et al. 2012) or the "ideal" rather actual higher-order identities (Berthold et al. 2012). Efforts to mitigate the harmful consequences of ingroup projection are driven mainly by the understanding of how higher-order categories are represented both cognitively and in discourse. Complex representations of higher-order identities should reduce ingroup projection. If the prototype is so complex that it must be characterized by a mix of subgroup traits, one group alone can hardly pretend to represent the prototype. Related to this observation, one may argue that representations of higher-order categories are not an objective and static feature but rather a social construction describing the struggle between subgroups to be better represented. Studies on the complexity of higher-order identities suggest the recognition of differences among subgroups as normative, which entails no claims of prototypicality

4 The perception that the ingroup prototype better represents the higher-order category than the outgroup prototype.

5 For a meta-analysis, see Wenzel et al. (2007); for a recent and throughout revision, see Wenzel et al. (2017). 
solely based on the values or attributes of just one group (Waldzus et al. 2003; Peker et al. 2010). The indispensability of subgroups within higher-order identities is another way to think about solving the problem of ingroup projection (Verkuyten et al. 2014).

In summary, there is a large amount of empirical evidence that demonstrates the theoretical predictions of the IPM. It varies across a wide range of contexts and situations, which makes the model both robust and regarded as a general model of intergroup relations with a high level of abstraction. However, because of its abstractness, it cannot be applied to any real-life context unless caveats are taken regarding the cultural, social, political or historical circumstances (Mummendey and Waldzus 2004). Among the wide range of contexts and situations in which the IPM has been tested, the European Union identity as a higher-order category has been among the first and most relevant (Wenzel et al. 2007; Mummendey and Waldzus 2004; Castano 2004; Wenzel et al. 2003). There are no studies, to the best of our knowledge, that discuss the European Union identity as an ingroup and the Mediterranean region as a regional higher-order category. The present study aims to undertake this endeavour.

\section{Normative Power Europe as an Ingroup Projection?}

One of the fruitful ways in which the IPM may deepen our understanding of how the EU can constitute a collective identity is in both supposedly separate debates on the interplay amid national identities and European identity and on the interaction between the EU and its others. Based on the dual function of categories as both self-categories and higher-order categories, it could be argued that the EU satisfies such conditions. Thus, in its role as a higher-order category, discourses about the EU as pluralistic, contested and negotiated might be explained by the different ingroup projections of nation states struggling to project their attributes onto the EU (Mummendey and Waldzus 2004). On the other hand, in its role as a self-category (ingroup) and taking into account that in categorization processes, both similarities within one's ingroup and differences from outgroups are accentuated, the normative nature of the EU's identity becomes clear in its international interactions, since "discourses of the EU as a normative power construct a particular self of the EU (and it is indeed perhaps the only form of identity that most of the diverse set of actors within the EU can agree on)" (Diez 2005, p. 614, emphasis added).

The IPM may shed light on formulations of the Mediterranean on behalf of region-building practices. The EU has constructed a notion of the Mediterranean through discursive practices of othering. Cebeci (2017) points to three Mediterranean constructions: the Mediterranean as a diverse geopolitical space, as a dangerous space and as a space that is crucial for EU interests. Boundary-identity exercises in these three Mediterranean constructions help build European identity as a united and well-integrated, secure, post-modern identity against a diverse and less-integrated, dangerous and modern Mediterranean other. Such identity-oppositional constructions create an "ideal" Europe against a barbarian Mediterranean other that helps to both produce the prototype of the Mediterranean region on ideal terms and shape the conceptions of what is to be considered normal in the Mediterranean. In other words, boundary-identity exercises legitimate the involvement of the European Union in the Mediterranean as a normative power. Empirical evidence has shown that constructions of the higher-order category in ideal terms intensify the process of ingroup projection, and even the higher-order category humanity produces greater ingroup projection from developed countries than from developing countries (Reese et al. 2012). Ingroup projection seems to be a process that applies everywhere, regardless of how complex higher-order categories might be.

$\mathrm{NPE}$, as a discursive representation of the EU's identity through the ingroup projection as a practice of differentiation, finds its best ground for empirical testing precisely in the Mediterranean. Bialasiewicz et al. (2009) point to the necessary discursive construction of the Mediterranean region to effectively exert normative power. He argues that "The projection of 'EU'rope southwards has required the symbolic, territorial and institutional construction of the Mediterranean for region-building initiatives [...] Region-making of this sort not only necessitates changes in political organization but also changes in structures of meaning; in effect, the discursive production of a Mediterranean regional 
space for projecting 'EU'rope" (Bialasiewicz et al. 2009, p. 83). It might be argued that discursive constructions of the Mediterranean (as a higher-order category) must be othering processes allowing changes in the structures of meaning. Therefore, the Mediterranean prototype is defined by the "EU" ropean prototype through ingroup projection. Constructions of the Mediterranean to overcome such a "Eurocentric" vision may be the Mediterranean as a shared identity, whereby processes of recategorization apply to the southern "other" to be more like the northern "self". Another method is the indispensability of subgroup identities to better define the prototype of the higher-order identity, which means that the Arab Mediterranean is indispensable to more reliably represent Mediterranean constructions. These alternatives are, to some extent, similar to what Nicolaïdis and Nicolaïdis (2006, p. 362) rightly call "the impossible choice between colonial nostalgia and integrative utopia".

In sum, two conclusions may stem from the analysis of the ingroup projection as a discursive practice of differentiation: first, in discursive constructions of the Mediterranean region, the EU's ingroup projection pretends to set the parameters about the content and meaning of "Mediterraneanness". Second, ingroup projection may be viewed as a practice of othering in the NPE discourse. The next section aims to demonstrate such understandings of ingroup projection empirically, examining the EU's response to the so-called Arab uprisings.

\section{Eu's Response to the Arab Uprising}

Before the Arab uprisings, the EU's support of authoritarianism in the southern Mediterranean on behalf of stability and security in the whole region was common, even acknowledging that this behaviour runs against the EU's vision as a normative power. With the analytical lens of the IPM, high-status groups may be more committed to shaping a shared system of norms and values through the tendency of ingroup projection emphasizing dominant narratives (Waldzus et al. 2004). If subgroups share a common vision about the higher-order prototype, they should agree on the relative position (value and status) they have in the social context. This consensus among groups leads to the legitimacy of intergroup differences, and neither group would claim the situation as discriminatory or unfair, legitimizing the status quo's narratives in favour of high-status groups. The authoritarian "south" agrees with the EU's Mediterranean vision embedded in the NPE discourse and hence accepts unequal treatment as legitimate. Nevertheless, southern autocrats were not interested in struggles over dominant narratives with which to obtain perceptions of legitimacy over the Mediterranean region; rather, they sought to reap the full benefits derived from relations with the EU through a "funnel" effect based on clientelism and the elite's corruption. Such an argumentation fits well with Del Sarto's (2016, p. 225) contention that "the MENA region exemplified the negative consequences of combining authoritarianism with market liberalization and privatization [...] As a result, elites increased their wealth and power, the gap between rich and poor grew wider, and unemployment soared". The EU's support for authoritarian regimes and consequently, the funnel effect caused in southern Mediterranean societies might have had some influence on the inception of the Arab uprisings at the end of 2010.

Bouazizi's desperate self-immolation led Arab people to occupy streets and squares from Tunisia to Egypt within a few months. Such events, largely unexpected by European political elites, united the Arab Mediterranean world to demand democracy, justice, dignity and the end of corruption. The IPM may explain such shifts in the Arab Mediterranean world. Notwithstanding the evidence that low-status groups accept inequalities based on the ingroup projection of high-status groups, this does not mean that low-status groups cannot display their own ingroup projection. Illegitimate relationships facilitate alternatives to the status quo that stimulate low-status groups to enhance their position (Ellemers et al. 1993). Low-status groups seek to enhance their representativeness in the intergroup social context by engaging in collective action, such as collective protests (e.g., Arab uprisings). The shared sense of frustration and oppression caused by years of authoritarian regimes backed by the EU containing migratory flows and the rise of Islamic extremism endowed the Arab uprisings with a regional identity, a shared Arab identity among southern Mediterranean people. 
This new Arab Mediterranean identity aimed to adopt many of the norms and values that the EU intended to project in its policies towards the Mediterranean. The Arab uprising has supposed a cognitive change to the EU's Mediterranean construction. It has been a (unforeseen) change of its constitutive other in the Mediterranean region, moving from an authoritarian "other" through which the differentiation is evident towards an "other(s)" who claims many of the norms and values that the European Union intends to project. What was the EU's response?

\section{The EU's Response as a Practice of "Othering"}

As the Arab uprisings highlighted the inconsistencies in the discourse articulations of the EU as a normative power, which for some scholars was one of the greatest challenges to this role of the EU in international politics (Diez 2013), the new southern other required a substantive adjustment of EU policies. Throughout 2011, the EU was forced to align itself with the narratives coming from the Arab uprisings, as the speech of the then Commissioner for Enlargement and Neighbourhood Policy Štefan Füle, showing a "mea culpa" narrative, reflects, pointing out that "Too many of us fell prey to the assumption that authoritarian regimes were a guarantee of stability in the region" (quoted in Leigh 2011). Another example of the alignment of the EU with the demands of the Arab uprisings was a speech made by the then president of the commission, José Barroso, underlining a sense of "we-ness" when he contends "I want to specifically say this to the young Arabs that are now fighting for freedom and democracy: We are on your side" (Barroso 2011). Furthermore, the first policy document specifically designed to address the events unfolding on the southern shore of the Mediterranean, the "Partnership for Democracy and Shared Prosperity", explicitly highlights such an alignment when it states "The changes now underway carry the hope of a better life for the people of the region and for greater respect of human rights, pluralism, rule of law and social justice-universal values that we all share" (European Commission and High Representative of the European Union for Foreign Affairs and Security Policy 2011a).

The sense of "we-ness" that seems to appear from the first responses by the EU has its raison d'etre in the new Arab Mediterranean identity that wants to achieve the values and norms that the EU has intended to project. The IPM might shed light on this new "self-other" relation in two contradictory directions: first, the effective recategorization of the new Arab identity, thus strengthening a new shared higher-order category (Mediterranean) where there is a consensus regarding the content and meaning of its prototype (for example, the indispensability of this new Arab Mediterranean identity to better characterize the Mediterranean region prototype). Second, the necessity for differentiation of this new other with which to obtain positive distinctiveness and thus be able to continue having the monopoly in the content and meaning of the prototype of the Mediterranean region as a higher-order category.

On the one hand, recategorizing means converting "other" into "self" under a shared identity, which implies having the same entitlements, status and legitimacy as the "self" (Weber et al. 2002). Unlike the enlargement process, the new Mediterranean "Other" will not accept status differences (ingroup projection) by the EU as legitimate, since the "quest for democratic freedoms is not something specific only to the European/Western arena, and they are very ripe for democracy - but their own democracy, not that imposed from outside" (Pace 2014, p. 976). Furthermore, the reluctance of external actors who have backed authoritarian regimes for the "sake" of stability and security in the Mediterranean could justify such behaviour. On the other hand, the necessity for differentiation is inherent in any intergroup interaction to obtain positive distinctiveness, as posited by SIT. Intergroup similarities may increase the tendency toward ingroup projection because they threaten positive distinctiveness (Mummendey and Wenzel 1999). Differentiation tends to persist even when there is intensive intergroup contact; when the self and other become increasingly familiar and alike, one must be aware of and protect what differentiates the self from the other (Rumelili and Todd 2018). The NPE discourse relies on both the exclusivity and normative differentiation of the European identity in foreign policy. In this way, the identity/difference paradox arises because if the EU and the new Arab Mediterranean "Other" became a single "self", the EU would lose its legitimacy in the Mediterranean 
and hence its normative power, as well as its constitutive other (Cebeci 2017). For this reason, the EU seeks to differentiate itself from its new other through discursive practices of othering embedded in legitimizing myths.

High-status or dominant groups foster ideologies that legitimate both the hierarchy and their position in a particular social system. Such groups endorse discourses that are usually considered legitimizing myths: "coherent sets of attitudes, values, beliefs, stereotypes and ideologies that provide moral and intellectual justification for the social practices that distribute social value within the social system" (Sidanius and Pratto 1999, p. 45). According to Sidanius and Pratto, legitimizing myths can be hierarchy-enhancing or hierarchy-attenuating. Hierarchy-enhancing myths are those that justify the existing status quo of the social system, favouring the position acquired by the high-status or dominant groups, whereas hierarchy-attenuating myths are those that try to balance the position and status of the groups inside a social system. For example, in cultural studies, assimilation strategies can be seen as a hierarchy-enhancing myth, since assimilation "requires immigrants to abandon their group identity and culture, and adapt and conform to the dominant group in the host society" (Hindriks et al. 2014, p. 540). On the other hand, multiculturalism strategies can be seen as a hierarchy-attenuating myth, as they require the majority group's acknowledgement of the identity, culture and social views of other groups.

In methodological terms, within the DHA frame of reference, assimilation or multiculturalism strategies may be considered topos in discursive strategies. In this sense, the legitimizing myths by which the EU tries to differentiate itself from the new Arab Mediterranean "other" are here seen as topos in the EU's ingroup projection as a discursive practice of othering. The Arab uprisings discredited and challenged some of the myths that the Western world, especially the EU, had established to differentiate itself from its Mediterranean other and thus legitimate its policies regarding the Mediterranean region. What the EU has been undertaking since 2011 is efforts to restore such myths.

Khader (2013) points out some myths that the Arab uprisings have challenged: first is the myth of the "Arab exception", which asserts that Arab people were not concerned with or qualified to advance democracy by themselves. The Global Strategy policy document (European External Action Service-EEAS 2016) employs words such as "acute", "plague" and "fragile" when referring to the southern Mediterranean. One inevitably envisages Arab Mediterranean societies with the lack of strength necessary to undertake democratic reforms and thus in need of external help in this endeavour. Furthermore, the "new response to a changing neighbourhood" document (European Commission and High Representative of the European Union for Foreign Affairs and Security Policy $2011 b)$ creates the concept of "deep democracy". It is a democracy "that lasts" insofar as the right to vote is complemented with other "attributes", such as "competing political parties, impartial justice or access to non-corrupt civil services" —attributes that "many Europeans take for granted" (European Commission and High Representative of the European Union for Foreign Affairs and Security Policy 2011 b, p. 5). Just by adding an adjective before the concept of democracy, the EU differentiates itself from the new Arab Mediterranean identity that has achieved just democracy (the right to vote) but still needs other "attributes" to be like Western democracies within the EU, and is therefore in need of help to achieve such a "mature" democracy. Another way to restore the Arab exception myth is the tendency of the EU to see the Arab others as "learners", which places the EU in the position of "teacher" (Cebeci and Schumacher 2017). Pace (2006) also outlines this representation when she says that "[the Mediterranean] becomes one of the generalized 'others' necessary for Europe's self-image [...] as learners or adopters of European norms" (Pace 2006, p. 92).

Another myth is the lack of an Arab identity - the belief that "the Arab world is, itself, a fiction and that the cross-border appeal of Arab identity had waned" (Khader 2013, p. 33). Although to some extent, the reinstating of this myth has been achieved by the diverging paths that the Arab uprisings have taken in states such as Tunisia, Syria, Libya or Egypt, erasing the sense of unity provided in the Arab uprisings, the EU also contributed to restoring such a myth by applying the principle of differentiation. Recent EU discourses that underline the Mediterranean other as inherently different and diverse (Cebeci 2017) or the most conflictual and least integrated region of the world (European 
External Action Service-EEAS 2017) seem to justify this principle. (Un)surprisingly, the differentiation principle, although first depicted in the 2004 ENP document, was not effectively implemented until the 2015 ENP review. Closely related to the earlier argumentation is the label of "advanced status" granted to Morocco and Tunisia by the EU. Although such "status" could be a natural consequence of the EU's enduring power of attraction, it could be read as a deliberative process of differentiation among Arab Mediterranean countries that legitimates the earlier discourse.

The third myth is what Khader (2013) describes as "Arab Street". This myth represents Arab people as anarchic, irrational and violent. The Arab uprisings questioned this myth as "there have always been forces of change bubbling above and below the surface and vibrant civil society organizations (CSOs)" (Khader 2013, p. 34). A common denominator after the Arab uprisings was the active engagement of the EU with CSOs sustained through economic and financial mechanisms, such as the Civil Society Facility and the European Endowment for Democracy. However, this engagement is as active as it is selective in the sense that it portrays civil society in a limited, liberal way, leaving aside relevant actors that emerged after the Arab uprising, such as CSOs with religious foundations. Such selective engagement has the aim of "producing neoliberal self-regulating subjects" (Cebeci and Schumacher 2017) and backing an elite civil society that is close to that under the former authoritarianism and is therefore detached from those who rose in revolt. Selective engagement with neoliberal CSOs serves to restore another related myth: neoliberal policies carried out in the Mediterranean naturally lead to healthy, strong and developed democracies (Del Sarto 2016). Moreover, selective engagement is legitimated with the EU's discourses portraying the EU as a standard that the other should follow and that the Arab change can only be achieved by CSO movements close to European values. Most of the post-uprising literature has continued to support such a Euro-centric approach even in the recent and scarce bottom-up studies, where "[EU] policies seek to foster a mode of subjectivity that is conducive to the EU's norms and objectives" (Tagma et al. 2013, p. 388), which demonstrates the "normative power" of the "normative power Europe" scholars (Cebeci 2012).

In the political realm, another myth was that Islamism is incompatible with democracy (Pace and Wolff 2017), with the experiences of Ennahda in Tunisia and the Muslim Brotherhood in Egypt as examples of Islamic political parties democratically elected after the Arab uprising. The EU has tended to view Islamism as a "monolithic threat" without considering (deliberatively or not) the profound changes that the Arab uprisings have brought in Arab politics (Al-Anani 2012; Bayat 2013; Pace and Wolff 2017). Although the new response of a changing neighbourhood document furthers "the emergence of democratic political parties that represent the broad spectrum of the views and approaches present in society" (European Commission and High Representative of the European Union for Foreign Affairs and Security Policy 2011b, p. 4. Emphasis added), the 2015 ENP review did not pretend to involve the growing diversity of Islamic actors that emerged after the Arab uprising. The lack of an "other" with which to interact after the uprisings led the EU to a state of uncertainty, preferring the former security/stability logic and supporting authoritarian regimes such as Al-Sisi in Egypt rather than engaging with the political alternatives that flourished after the Arab spring.

\section{Conclusions}

The unforeseen cognitive change that the Arab uprisings brought about questioned most of the myths that the EU built to legitimate its asymmetrical policies in the Mediterranean. The most concrete influence on legitimacy occurs when people make decisions or enforce rules meant to shape the behaviour of others, and that is the main aim of the Normative Power Europe discourse- to shape conceptions of what is normal. The EU has been restoring these myths again through ingroup projection as a discursive/cognitive practice of othering. By the principle of differentiation, the EU satisfies the inherent tendency to give positive value to its own group. Such constructions of the Mediterranean other inevitably lead to the self-construction of the EU on ideal terms and therefore to an ingroup projection process by which the Mediterranean region is portrayed on the EU's ideal terms, legitimizing the EU's policies. The selective engagement with CSOs and political actors has the aim of constituting 
a new other that agrees with the relative prototypes and hence accepts unequal treatment as legitimate, restoring the pre-Arab uprising status quo in the Mediterranean.

The social-psychological dimension of the NPE discourse through the ingroup projection as a practice of othering contributes to deepening our understanding of the foreign policy/identity debate, providing alternative explanations to the EU's enlargements or its interaction with international actors in region-building initiatives, such as those in the Mediterranean.

The dual function of categories as self and higher-order categories also extends the two-level debate on the interplay between national identities and European identity and on the interaction between the EU and its international others. Addressing the EU's identity as both a higher-order category and a self-category might render a unique framework with which to analyse this two-level debate. Issues such as the EU debt crisis, which split the EU's states as debtors and creditors, or the recent rise of right-wing extremism in some EU countries, which jeopardizes the normative foundations of the EU identity, could address this new analytical framework.

One may claim that ingroup projection, as specified in the IPM, is a cognitive othering practice with which the NPE discourse tries to legitimate self/other relationships. This paper helps develop the psychological/cognitive dimension of the Normative Power Europe discourse. In this sense, this analytical lens offers new ways to understand the way the EU's legitimacy is established.

Author Contributions: Conceptualization, J.J.T.-L.; methodology, J.J.T.-L.; formal analysis, J.J.T.-L.; writing一original draft preparation, J.J.T.-L.; writing - review and editing, J.J.T.-L. and E.G.-G.; supervision, E.G.-G. All authors have read and agreed to the published version of the manuscript.

Funding: This research was partially funded by Spanish MCINN: Project ECO2017-82347-P.

Conflicts of Interest: The authors declare no conflict of interest

\section{References}

Al-Anani, Khalil. 2012. Islamist Parties post-Arab Spring. Mediterranean Politics 17: 466-72. [CrossRef]

Aydın-Düzgit, Senem. 2014. Critical discourse analysis in analysing European foreign policy: Prospects and challenges. Cooperation and Conflict 49: 354-67. [CrossRef]

Barroso, Jose. 2011. Statement by President Barroso on the Situation in North Africa. Available online: http://europa.eu/rapid/press-release_SPEECH-11-137_en.htm (accessed on 6 April 2018).

Bayat, Asef. 2013. Post-Islamism: The Changing Faces of Political Islam. Oxford: Oxford University Press. [CrossRef]

Berthold, Anne, Amélie Mummendey, Thomas Kessler, Bastian Luecke, and Thomas Schubert. 2012. When different means bad or merely worse. How minimal and maximal goals affect ingroup projection and outgroup attitudes. European Journal of Social Psychology 42: 682-90. [CrossRef]

Bialasiewicz, Luiza, Carl Dahlman, Gian Matteo Apuzzo, Felix Ciutǎ, Alun Jones, Chris Rumford, Ruth Wodak, James Anderson, and Alan Ingram. 2009. Interventions in the New Political Geographies of the European 'Neighbourhood'. Political Geography 28: 79-89. [CrossRef]

Bicchi, Federica. 2006. Our Size Fits All: Normative Power Europe and the Mediterranean. Journal of European Public Policy 13: 286-303. [CrossRef]

Campbell, David. 1998. Writing Security. United States Foreign Policy and the Politics of Identity. Minneapolis: University of Minnesota Press.

Campbell, David. 2013. Poststructuralism. In International Relations Theories. Discipline and Diversity, 3rd ed. Edited by Timothy Dunne, Milja Kurki and Steve Smith. Oxford: Oxford University Press, pp. 223-46.

Castano, Emanuele. 2004. European Identity: A Social-Psychological Perspective. In Transnational Identities: Becoming European in the EU. Edited by Richard K. Herrmann, Thomas Risse-Kappen and Marilynn B. Brewer. New York: Rowman and Litlltefield, pp. 40-58.

Cebeci, Münevver. 2012. European Foreign Policy Research Reconsidered: Constructing an 'Ideal Power Europe' through Theory? Millennium: Journal of International Studies 40: 563-83. [CrossRef]

Cebeci, Münevver. 2017. The EU's Constructions of the Mediterranean. MEDRESET Policy Papers. June 1. Available online: medreset.eu (accessed on 17 September 2019).

Cebeci, Münevver, and Tobias Schumacher. 2017. The EU's Constructions of the Mediterranean (2003-2017). MEDRESET Working Papers. April 3. Available online: medreset.eu (accessed on 17 September 2019). 
Commission of the European Communities. 2003. 'Wider Europe. Neighbourhood: A New Framework for Relations with Our Eastern and Southern Neighbours', (COM/2003/104). March 11. Available online: eeas.europa.eu (accessed on 6 April 2018).

Del Sarto, Raffaella. 2016. Normative Empire Europe: The European Union, Its Borderlands, and the 'Arab Spring'. Journal of Common Market Studies 54: 215-32. [CrossRef]

Diez, Thomas. 2005. Constructing the Self and Changing Others: Reconsidering 'Normative Power Europe'. Millennium: Journal of International Studies 33: 613-36. [CrossRef]

Diez, Thomas. 2013. Normative power as hegemony. Cooperation and Conflict 48: 194-210. [CrossRef]

Doty, Roxanne Lynn. 1996. Imperial Encounters: The Politics of Representation in North-South Relations. Minneapolis: University of Minnesota Press.

Ellemers, Naomi, Henk Wilke, and Ad Van Knippenberg. 1993. Effects of the legitimacy of low group or individual status on individual and collective status-enhancement strategies. Journal of Personality and Social Psychology 64: 766-78. [CrossRef]

European Commission and High Representative of the European Union for Foreign Affairs and Security Policy. 2011a. A Partnership for Democracy and Shared Prosperity with the Southern Mediterranean. (COM/2011/200). March 8. Available online: ec.europa.eu (accessed on 6 April 2018).

European Commission and High Representative of the European Union for Foreign Affairs and Security Policy. 2011b. A New Response to a Changing Neighbourhood: A Review of European Neighbourhood Policy. (COM/2011/303). May 25. Available online: ec.europa.eu (accessed on 6 April 2018).

European External Action Service-EEAS. 2016. Shared Vision, Common Action: A Stronger Europe. A Global Strategy for the European Union's Foreign and Security Policy. June 28. Available online: eeas.europa.eu (accessed on 18 October 2019).

European External Action Service-EEAS. 2017. Opening Remarks by the High Representative Federica Mogherini at the Second Regional Forum of the Union for the Mediterranean (UfM). Brussels. January 23. Available online: eeas.europa.eu (accessed on 18 October 2019).

Hansen, Lene. 2006. Security as Practice: Discourse Analysis and the Bonian War. London: Routledge.

Haukkala, Hiski. 2011. The European Union as a Regional Normative Hegemon: The Case of European Neighbourhood Policy. In Normative Power Europe. Empirical and Theoretical Perspectives. Edited by Richard G. Whitman. London: Palgrave Macmillan, pp. 45-64. [CrossRef]

Hindriks, Paul, Maykel Verkuyten, and Marcel Coenders. 2014. Dimensions of Social Dominance Orientation: The Roles of Legitimitizing Myths and National Identification. European Journal of Personality 28: 538-49. [CrossRef]

Khader, Bichara. 2013. The European Union and the Arab World: From the Rome Treaty to the Arab Spring. Barcelona: IEMed/EuroMeSCo, Available online: www.iemed.org (accessed on 6 April 2018).

Leigh, Phillips. 2011. Europe 'Should Have Backed Democrats Not Dictators, Commissioner Says. EU Observer. Available online: euobserver.com (accessed on 6 April 2018).

Manners, Ian. 2002. Normative Power Europe: A Contradiction in Terms? Journal of Common Market Studies 40: 235-58. [CrossRef]

Manners, Ian, and Richard G. Whitman. 2003. The "difference engine": Constructing and representing the international identity of the European Union. Journal of European Public Policy 10: 380-404. [CrossRef]

Mummendey, Amélie, and Sven Waldzus. 2004. National differences and European plurality: Discrimination or tolerance between European countries. In Transnational Identities: Becoming European in the EU. Edited by Richard K. Herrmann, Thomas Risse and Marilyn B. Brewer. New York: Rowman \& Littlefield, pp. 59-72.

Mummendey, Amélie, and Michael Wenzel. 1999. Social discrimination and tolerance in intergroup relations: Reactions to intergroup difference. Personality and Social Psychology Review 3: 158-74. [CrossRef] [PubMed]

Neumann, Iver B. 1998. European Identity, EU Expansion, and the Integration/Exclusion Nexus. Alternatives 23: 397-416. [CrossRef]

Nicolaïdis, Kalypso, and Robert Howse. 2002. "This Is my EUtopia ... ": Narrative as Power. Journal of Common Market Studies 40: 767-92. [CrossRef]

Nicolaïdis, Kalypso, and Dimitri Nicolaïdis. 2006. The EuroMed beyond Civilizational Paradigms. In The Convergence of Civilizations: Constructing a Mediterranean Region. Edited by Emanuel Adler, Beverly Crawford, Federica Bicchi and Raffaella Del Sarto. Toronto: University of Toronto Press, pp. 337-78. 
Oakes, Penelope, Alexander S. Haslam, and John C. Turner. 1998. The role of prototypicality in group influence and cohesion: Contextual variation in the graded structure of social categories. In Social Identity: International Perspectives. Edited by Stephen Worchel, J. F. Morales, Darío Páez and JeanClaude Deschamps. London: Sage, pp. 75-92.

Pace, Michelle. 2006. The Politics of Regional Identity. Meddling with the Mediterranean. London and New York: Routledge. Pace, Michelle. 2014. The EU's Interpretation of the 'Arab Uprisings': Understanding the Different Visions about Democratic Change in EU-MENA Relations. Journal of Common Market Studies 52: 969-84. [CrossRef]

Pace, Michelle, and Sarah Wolff. 2017. The European Neighbourhood Policy and Islamist actors in the southern neighbourhood. In Routledge Handbook on the European Neighbourhood Policy. Edited by Tobias Schumacher, Andreas Marchetti and Thomas Demmelhuber. Oxford: Taylor \& Francis, pp. 507-18. [CrossRef]

Peker, Müjde, Richard J. Crisp, and Michael Hogg. 2010. Predictors of ingroup projection: The roles of superordinate category coherence and complexity. Group Processes and Intergroup Relations 13: 525-42. [CrossRef]

Reese, Gerhard, Anne Berthold, and Melanie Steffens. 2012. We are the world-And they are not: Prototypicality for the world community, legitimacy and responses to global inequality. Political Psychology 33: 683-700. [CrossRef]

Reisigl, Martin, and Ruth Wodak. 2001. Dicourse and Discrimination: Rethorics of Racism and Antisemitism. London and New York: Routledge.

Rumelili, Bahar. 2004. Constructing Identity and Relating to Difference: Understanding the EU's Mode of Differentiation. Review of International Studies 30: 27-47. [CrossRef]

Rumelili, Bahar, and Jennifer Todd. 2018. Paradoxes of identity-change: Integrating macro, meso and micro research on identity in conflict processes. Politics 38: 3-18. [CrossRef]

Schimmelfennig, Frank. 2001. The Community Trap: Liberal Norms, Rhetorical Action, and the Eastern Enlargement of the European Union. International Organization 55: 47-80. [CrossRef]

Sidanius, Jim, and Felicia Pratto. 1999. Social Dominance: An Intergroup Theory of Social Hierarchy and Opression. Cambridge: Cambridge University Press.

Tagma, Halit, Elif Kalaycioglu, and Emel Akcali. 2013. 'Taming' Arab Social Movements: Exporting Neoliberal Governmentality. Security Dialogue 44: 375-92. [CrossRef]

Tajfel, Henry, and John C. Turner. 1986. The social identity theory of intergroup behavior. In Psychology of Intergroup Relations. Edited by Stephen Worchel and William G. Austin. Chicago: Nelson-Hall Publishers, pp. 7-24.

Tajfel, Henry, Michael G. Billig, Robert P. Bundy, and Claude Flament C. 1971. Social categorisation and intergroup behavior. European Journal of Social Psychology 1: 149-78. [CrossRef]

Turner, John C. 1987. A self-categorisation theory. In Rediscovering the Social Group: A Self-Categorisation Theory. Edited by John C. Turner, Michael A. Hogg, Penelope J. Oakes, Stephen D. Reicher and Margaret S. Wetherell. Oxford: Blackwell, pp. 42-67.

Ullrich, Johannes, Oliver Christ, and Elmar Schlüter. 2006. Merging on Mayday: Subgroup and superordinate identification as joint moderators of threat effects in the context of European Union's expansion. European Journal of Social Psychology 36: 857-75. [CrossRef]

Verkuyten, Maykel, Borja Martinovic, and Anouk Smeekes. 2014. 'The multicultural jigsaw puzzle: Category indispensability and acceptance of inmigrants' cultural rights. Personality and Social Psychology Bulletin 40: 1480-93. [CrossRef]

Waldzus, Sven, Amélie Mummendey, Michael Wenzel, and Ulrike Weber. 2003. Towards tolerance: Representations of superordinate categories and perceived in-group prototypicality. Journal of Experimental Social Psychology 39: 31-47. [CrossRef]

Waldzus, Sven, Amélie Mummendey, Michael Wenzel, and Franzisca Boettcher. 2004. Of bikers, teachers and Germans: Groups' diverging views about their prototypicality. British Journal of Social Psychology 43: 385-400. [CrossRef] [PubMed]

Weber, Ulrike, Amélie Mummendey, and Sven Waldzus. 2002. Perceived legitimacy of intergroup status differences: Its prediction by relative ingroup protypicality. European Journal of Social Psychology 32: 449-70. [CrossRef]

Wenzel, Michael, Amélie Mummendey, Ulrike Weber, and Sven Waldzus. 2003. The ingroup as pars pro toto: Projection from the ingroup onto the inclusive category as a precursor to social discrimination. Personality and Social Psychology Bulletin 29: 461-73. [CrossRef] 
Wenzel, Michael, Amélie Mummendey, and Sven Waldzus. 2007. Superordinate identities and intergroup conflict: The ingroup projection model. European Review of Social Psychology 18: 331-72. [CrossRef]

Wenzel, Michael, Sven Waldzus, and Melanie C. Steffens. 2017. Ingroup projection as a challenge of diversity: Consensus about and complexity of superordinate categories. In The Cambridge Handbook of the Psychology of Prejudice. Edited by Chris G. Sibley and Fiona K. Barlow. Cambridge: Cambridge University Press, pp. 65-89. [CrossRef]

Wodak, Ruth. 2001. The Discourse-Historical Approach. In Methods of Critical Discourse Analysis. Edited by Ruth Wodak and Michael Meyer. London: Sage, pp. 63-94. [CrossRef] 